Desai, R., \& Desai, J. (2020). Moderating effect of firm size on capital structure determinants: evidence from Indian food processing industry. Copernican Journal of Finance \& Accounting, 9(3), 61-81. http://dx.doi.org/10.12775/CJFA.2020.012

\author{
Rajesh Desai* \\ Chimanbhai Patel Institute of Management and Research
}

JaY Desal ${ }^{* *}$

B.K. School of Business Management

\title{
MODERATING EFFECT OF FIRM SIZE ON CAPITAL STRUCTURE DETERMINANTS: EVIDENCE FROM INDIAN FOOD PROCESSING INDUSTRY
}

Keywords: determinants, capital structure, food processing, size, moderation.

J E L Classification: G30, G32.

Abstract: Present research paper examines the determinants of capital structure deci-
sion of Indian food processing industry and assesses the moderating effect of firm size
on this relationship. Using financial data of 40 firms for 10 years (2009-10 to 2018-19),
panel least square regression analysis has been performed for data analysis. Based on
regression results, the study concludes tangibility, tax rate, and cash flow as signifi-
cant determinants of long-term borrowing for overall sample firms. On the other hand,
tangibility, liquidity and profitability are significant factors affecting short-term bor-
rowings of selected companies. Further, the study confirms that size of the firm mode-
rates the effect of selected determinants on debt ratio of different categories of firms.

Date of submission: July 13, 2020; date of acceptance: October 10, 2020.

* Contact information: rajesh.desai8@gmail.com, Chimanbhai Patel Institute of Management and Research, Ahmedabad Gujarat, India - 380015, phone: 9904042289; ORCID ID: https://orcid.org/0000-0003-3611-8409.

** Contact information: jay@jaydesai.net, B.K. School of Business Management, Ahmedabad, Gujarat, India - 380015, phone: 9879212369; ORCID ID: https:/orcid.org/ 0000-0001-6707-8580. 
It is, further, found that small size firms employ more debt with increasing profitability whereas medium and large size firms tend to reduce their debt levels with increasing profitability. The research findings will enhance understanding of capital structure determinants by probing the moderating impact of company size on it. The findings will be helpful to corporate managers in forming their borrowing strategies based on the relative size. Further, they can identify important factors to be considered while choosing debt or equity or in case of debt either short term or long term.

\section{IIIIRTODUCTION}

In current scenario, one of the major challenges faced by finance managers is to decide about the optimal source of funds. A business may be financed by combination of debt and equity funds termed as 'capital structure (CS)' and the choice of CS is governed by costs and benefits associated with the given source of financing. Debt funds act as tax shield as interest payments are allowed under tax laws (Modigliani \& Miller (MM), 1963) and it does not affect the decision authority of managers (Myers \& Majluf, 1984) but excessive use of debt creates financial burden on firms and enhances the risk of bankruptcy. On the other hand, equity funds do not require fix coupon payment and can help in maintaining the cost of financial distress (Myers, 1984) but mere dependence on equity funds increases the cost of financing as investors perceive it as riskier avenue and expect premium for the same. Hence, every firm needs to opt for such combination of debt and equity that maximizes value of its shareholders. CS has remained the most debatable issue in literature as well as it is a vital decision for managers to make. Further, choice of an optimal CS is a function of multiple factors that vary across various economies and even across industries operating in same economy.

David Durand (1952) has ignited research in this area through 'net operating income (NOI) approach' and concluded that value of the firm is independent of CS. Modigliani and Miller (1958) have enlightened the issue of financing decision with their 'theory of irrelevance' and confined the conclusion given by David Durand (1952). Later, MM (1963) have made a correction in form of tax benefits due to debt issue and concluded positive effect of debt on firm value. In 1963, Ezra Solomon has contradicted the irrelevance approach and stated that higher debt can reduce the overall cost of funds as cost of debt is lower than that of equity. Besides financial factors, various theories have proposed behavioral and non-financial aspects affecting the CS choice. Pecking order theory (POT), first proposed by Donaldson (1961) and later developed by Myers and 
Majluf (1984), does not emphasis on an optimal CS but provides preferential order of financing followed by firms. The theory states that profitable firms usually depend more on retained profits for financing new or existing projects which is followed by borrowings and the last preference is given to ordinary equity. Agency cost theory (ACT) (Meckling \& Jensen, 1976) emphasizes on the issue of separation of ownership and control arising from issue of debt or/and equity. It results into conflicting interest of managers \& equity holders as well as equity holders and lenders. The theory concludes that borrowings act as a financial control on managers in form of compulsory interest payments and reduce wasteful spending. Myers (1984) has explained the existence of an optimal debt-equity ratio using trade-off theory (TOT). Interest payment provides tax advantage but also adds to the cost of financial distress and therefore firms attempt to tradeoff between them by balancing the debt-equity proportions. According to Myers (2003), a firm should equate the present value of cost of financial distress with that of interest tax shield to arrive at an optimal CS. An abridged view of CS theories has been presented in figure 1 .

Figure 1. CS Theories

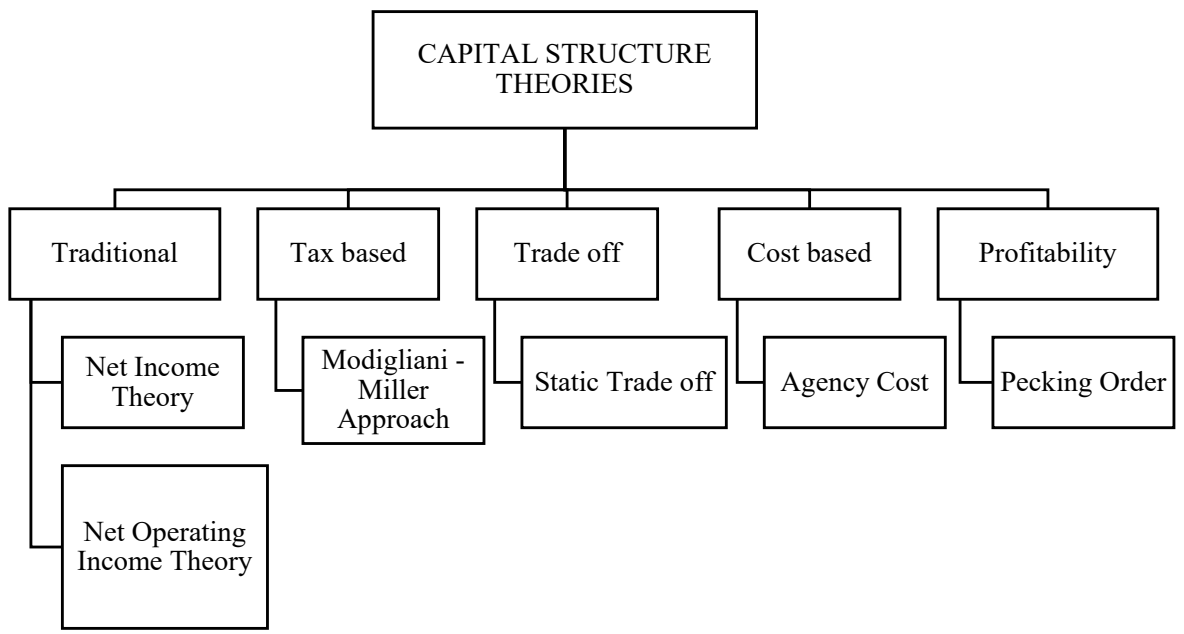

S o u r c e : compiled by author.

Besides theatrical contributions, ample of empirical inquiries have been conducted on determinants of CS but results are inconclusive (Bhaduri, 2002; 
Rani, Narain \& Dhawan, 2016; Sathyanarayana, Harish \& Kumar, 2017; Iqbal, Ahmad \& Ali, 2019; Vintila, Gherghina \& Toader, 2019). Such indecisive research findings require further empirical evidence to support the theatrical underpinnings. Present study attempts to add value to the existing literature in two ways. First, the study incorporates the moderating effect of firm size by categorizing them into various sub-samples. Panel regression analysis has been performed for overall sample as well as for sub-samples to assess this moderating effect. Second, though past studies have examined the determinants of CS in Indian context, limited evidence is available on food processing industry (Aggarwal \& Acharya, 2019) and hence the study attempts to bridge the gap in the existing literature.

The food processing industry is the $5^{\text {th }}$ largest industry in terms of production, consumption, export, and expected growth in India. It worth USD 65.4 billion in 2018 and growing at compounded annual growth rate (CAGR) of 11 percent. It contributes nearly 14 percent to gross domestic product (GDP), 13 percent to export and 6 percent to total industrial investment and it is expected to reach USD 894.98 billion by 2020 (Brand India, 2017). Government initiatives such as foreign collaborations, industry licenses, 100 percent export-oriented units, mega food parks, infrastructure for agro-processing clusters, and operation greens are major growth drivers of this industry (Ministry of Food Processing Industries, 2019).

The remainder of this study proceeds as follows: the following section describes the research methodology and process. This is followed by the review of the literature and formulation of hypotheses. Third section presents the outcome of the data analysis and result discussion. The final section includes the implication of the study, direction of future research, and the conclusion.

\section{RESEARCH METHODOLOGY AND THE COURSE OF RESEARCH PROCESS}

Primarily, the study is aimed to examine the determinants of CS decision in food processing industry of India considering the moderating effect of firm size. Out of total 66 listed companies, 12 companies, listed for less than 10 years, and 14 companies, with incomplete data, are dropped from the sample. Finally, 40 companies with complete financial data of 10 years (2009-10 to 2018-19) are considered as sample and a balanced panel data set of 400 firm-year observations has been developed. 
To assess the moderating effect of firm size, companies are classified as Small (Asset Value $<100 \mathrm{Cr}$.), Medium (100 Cr. to $500 \mathrm{Cr}$.), and Large ( $>500 \mathrm{Cr}$.). Financial data has been collected from PROWESS - Center for Monitoring Indian Economy (CMIE) database. CMIE is one of the largest databases available on Indian companies and economy and has been referred in several past empirical studies as source of data (Mallikarjunappa \& Goveas, 2007; Gupta, 2015; Aggarwal \& Acharya, 2019). The study adopts panel least square regression methodology for econometric analysis.

\section{LITERATURE REVIEW AND HYPOTHESIS DEVELOPMENT}

\section{Tangible Assets}

Long-term debts are usually secured by pledging fixed assets with banks because of large amount and longer repayment period. Higher proportion of fixed assest (termed as Tangibility) facilitates debt raising for companies (M'ng, Rahman \& Sannacy, 2017; Sathyanarayana et al., 2017; Yousef, 2019). On the contrary, ACT (Ross, 1977) supports negative relationship between tangibility and debt ratio. ACARAVCI (2015) has validated the conclusion of ACT through statistical evidence. Following the conclusion of past results, the study hypothesized positive effect of tangible assets on debt ratio.

$\mathrm{H}_{1}$ : There is a significant positive relationship between asset tangibility and debt financing.

\section{Liquidity}

Liquidity shows the ability of a firm to meet its' short term obligations. Ramli, Latan and Solovida (2019) have suggested direct impact of liquidity as higher current ratio indicates capabilities to stand against short-term financial crisis. As against this, POT and ACT signifies that greater liquidity results into less borrowings as it ensures sufficient funds and less requirement of external funds (Berkman, İskenderoğlu, Karadeniz \& Ayyildiz, 2016; Vintila et al., 2019). Following the conclusion of POT and TOT, negative relationship has been predicted between liquidity and borrowings.

$\mathrm{H}_{2}$ : There is a significant negative relationship between liquidity and debt financing. 


\section{Opportunities of growth}

Abor (2007) proposed that growing firms require capital to finance large scale operations. Besides, growing firms prefers debt as compared to equity to avail favorable financial leverage hence growth has positive impact on debt ratio (Rani et al., 2016; Sathyanarayana et al., 2017; Mayuri \& Kengatharan, 2019). On the contrary, TOT and ACT proposed negative relation between growth and debt financing as growing firms are more exposed to losses in case of financial distress (Yousef, 2019) due to their instable earnings (Bauer, 2004). Based on the research output of emerging economies, positive relationship has been assumed between growth and borrowings.

H3: There is a significant positive relationship between growth and debt financing.

\section{Profitability}

Positive and consistent financial performance act as an attraction for lenders and banks as it ensures safety of funds and regular returns. Profitability improves borrowing power of firms and gives positive signal in the capital market (Ross, 1977; Myers \& Majluf, 1984). This positive relationship has been confimed by Dakua (2018), Ramli et al. (2019) and Rao, Kumar and Madhvanal (2019). On the contrary, companies with stable profits gradually discharge their liabilities and become less dependent on external funds. Profitbale firms rely on internally generated funds and hence there exists inverse relationship between profitability and leverage (Bauer, 2004; Iqbal et al., 2019). Though empirical findings are inconsistent, the present study assumes negative impact of profitability on borrowings following research findings from emerging economies (Gupta, 2015; Abor, 2005 \& 2007; Banerjee \& De, 2014).

$\mathrm{H}_{4}$ : There is a significant negative relationship between profitability and debt financing.

\section{Rate of tax}

Interest payment on debt reduces tax liability and hence value of the levered firm will be higher than unlevered firm to the extent of tax savings on financial cost (MM, 1963). Though theatrically it is inferred that tax rate has positive re- 
lation with leverage, very few empirical studies have proved the same (Bauer, 2004). Based on conclusion from MM (1963), the study presumes positive impact of tax rate on debt ratio.

$\mathrm{H}_{5}$ : There is a significant positive relationship between rate of tax and debt financing.

\section{Non-debt tax shield}

Fama and French (1998) have concluded that actual tax benefits availed from debt financing are considerably lower than what promised theatrically. Against this, non-debt tax shield such as depreciation and amortisation may serve as an alterantive to reduce tax liabilities (DeAngelo \& Masulis, 1980). Therefore, non-debt tax shield has negative impact on debt-financing (Hossain \& Hossain, 2015; Vijayalakshami, 2016).

$\mathrm{H}_{6}$ : There is a significant negative relationship between non-debt tax shield and debt financing.

\section{Cash flow}

According to TOT, firms with higher cash flows are exposed to less risk and hence able to borrow easily indicating direct impact of cash flow on debt financing (Myers, 1984). On the contrary, according to POT, internally generated cash flows can be used as alternative source of funds hence higher level of cash flows tend to reduce debt ratios (Myers \& Majluf, 1984). Empirical findings have reported contradictory results on relation between cash flows and borrowings (Hossain \& Hossain, 2015; Karadeniz, Kandir, Balcilar \& Onal, 2009; Bhaduri, 2002). Hence, the relationship between borrowings and cash flows requires further probing.

$\mathrm{H}_{7}$ : There is a significant relationship between cash flows and debt financing.

\section{Debt-coverage capacity}

Firms with higher debt should earn enough earnings to serve interst cost of borrowings. High degree of debt service capacity depicts ability of firm to meet its fixed interest obligations evenif operating profits decline considera- 
bly. Hence borrowings are directly correlated with debt coverage ratio of firms (Mittal \& Singla, 1992; Mallikarjunappa \& Goveas, 2007).

H8: There is a significant positive relationship between debt-coverage and debt financing.

\section{Research gap and conceptual model}

Though substantial literature is available on capital structure determinants, the outcomes are inconclusive and contradictory. Besides, very limited research work is carried out by including food processing indutry except by Aggarwal and Acharya (2019) who have focused on medium size firms only. Further, factors affecting financing choice and their strength may vary due to firm size. Therefore, this paper attempts to fill this gap and add value to the existing pool of literature. Figure 2 indictes the conceptual model developed from review of exatant literature.

Figure 2. Conceptual Model of CS Determinants

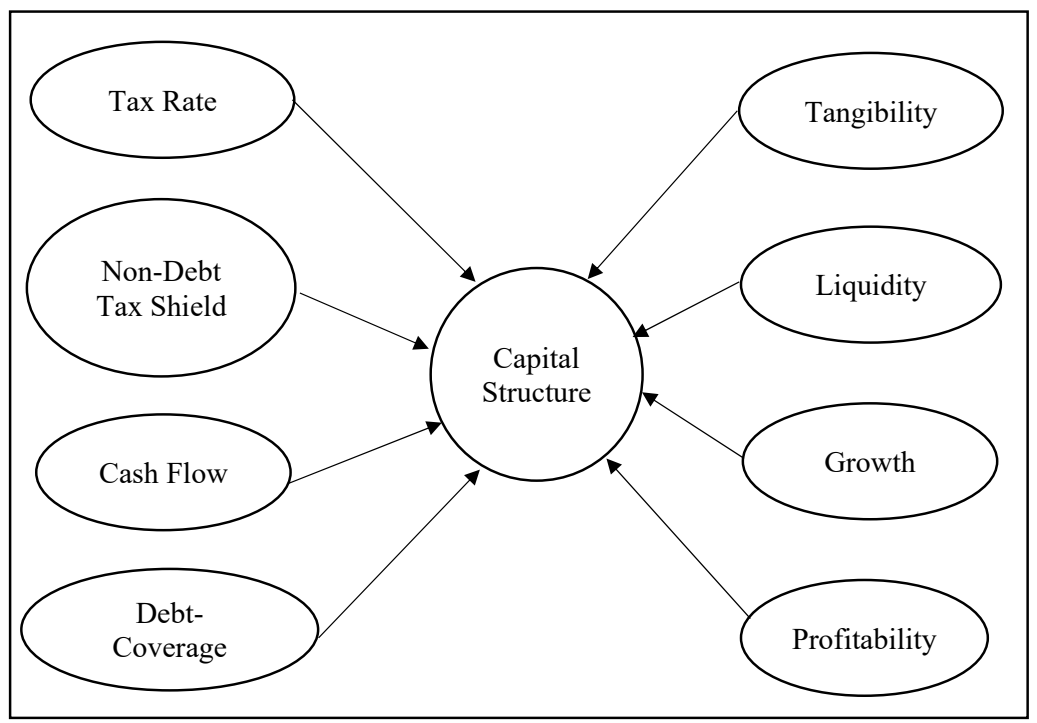

N o t e s: Capital Structure has been measured by long-term debt ratio and short-term debt ratio. S o u r c e : developed by author. 


\section{DETERMINATION OF VARIABLES AND ECONOMETRIC METHODS}

\section{Variables of the study}

Table 1 presents the variables included in the study along with their computation and source of inclusion.

Table 1. Operationalization of Variables

\begin{tabular}{|c|c|c|}
\hline Variable Name & Computation & Source \\
\hline \multicolumn{3}{|c|}{ Dependent Variables } \\
\hline Long-Term Debt Ratio (LTLR) & $\frac{\text { Long Term Debt }}{\text { Total Asset }}$ & $\begin{array}{l}\text { Rao et al. (2018); lqbal et al. } \\
\text { (2018); Abor (2005) }\end{array}$ \\
\hline Short-Term Debt Ratio (STLR) & $\frac{\text { Short Term Debt }}{\text { Total Asset }}$ & Rao et al. (2018), Abor (2007) \\
\hline \multicolumn{3}{|c|}{ Indepndent Variables } \\
\hline Tangibility (TAS) & $\frac{\text { Net Fixed Assets }}{\text { Total Assets }}$ & Rani et al. (2016); Yousef (2019) \\
\hline Liquidity (LQD) & $\frac{\text { Current Asset }}{\text { Current Liabilities }}$ & $\begin{array}{l}\text { Berkman et al. (2016); Vintila et } \\
\text { al. (2019) }\end{array}$ \\
\hline Opportunity of Growth (OPGR) & $\frac{\text { Sale }_{n}-\text { Sale }_{n-1}}{\text { Sale }_{n-1}}$ & $\begin{array}{l}\text { Kazmierska-Jozwiak, Marszalek } \\
\text { \& Sekula (2015); Roa et al. (2019) }\end{array}$ \\
\hline Profitability (PRFT) & $\frac{\text { EBIT }}{\text { Total Asset }}$ & Bauer (2004); Vintila et al. (2019) \\
\hline Rate of Tax (RTX) & $\frac{\text { Provision of Tax }}{\text { Profit Before Tax }}$ & $\begin{array}{l}\text { Ramaratnam \& Jayaraman (2013); } \\
\text { Vijayalakshami (2016) }\end{array}$ \\
\hline Non-Debt Tax Shield (NDT) & $\frac{\text { Depreciation }}{\text { Total Assets }}$ & $\begin{array}{l}\text { Vijayalakshami (2016); Ramli et } \\
\text { al. (2019) }\end{array}$ \\
\hline Cash Flow to Assets (OCFA) & $\frac{\text { Operating Cash Flow }}{\text { Total Assets }}$ & Rao et al. (2018) \\
\hline Debt-Coverage Capacity (DCC) & $\frac{\text { EBIT }}{\text { Interest Expenses }}$ & $\begin{array}{l}\text { Mittal \& Singla (1992); Mallikarju- } \\
\text { nappa \& Goveas (2007) }\end{array}$ \\
\hline
\end{tabular}

S o u r c e : own study based on literature review, 2020. 


\section{Econometric models}

As the study is based on cross-sectional time series data, panel least square regression analysis has been adopted for analysis. Equation 1 and 2 presents the econometric model formed by considering LTLR and STLR as dependent variables, respectively.

$\mathrm{LTLR}_{\mathrm{it}}=\beta_{0}+\beta_{1} \mathrm{TAS}_{\mathrm{it}}+\beta_{2} \mathrm{LQD}_{\mathrm{it}}+\beta_{3} \mathrm{OPGR}_{\mathrm{it}}+\beta_{4} \mathrm{PRFT}_{\mathrm{it}}+\beta_{5} \mathrm{RTX}_{\mathrm{it}}+\beta_{6} \mathrm{NDT}_{\mathrm{it}}+$ $\beta_{7} \mathrm{OCFA}_{\mathrm{it}}+\beta_{8} \mathrm{DCC}_{\mathrm{it}}+\varepsilon_{\mathrm{it}}$

$\operatorname{STLR}_{\text {it }}=\beta_{0}+\beta_{1} \mathrm{TAS}_{\mathrm{it}}+\beta_{2} \mathrm{LQD}_{\mathrm{it}}+\beta_{3} \mathrm{OPGR}_{\mathrm{it}}+\beta_{4} \mathrm{PRFT}_{\mathrm{it}}+\beta_{5} \mathrm{RTX}_{\mathrm{it}}+\beta_{6} \mathrm{NDT}_{\mathrm{it}}+$ $\beta_{7} \mathrm{OCFA}_{\mathrm{it}}+\beta_{8} \mathrm{DCC}_{\mathrm{it}}+\varepsilon_{\mathrm{it}}$

Where,

$\beta_{0}=$ Intercept

$\beta_{1}$ to $\beta_{8}=$ Regression co-efficient

$\varepsilon=$ Error Term

$\mathrm{i}=$ Number of Firm (1 to 40)

$t=$ Number of Year (2008-09 to 2018-19)

\section{DATA ANALYSIS AND RESULTS}

\section{Descriptive statistics}

Table 2 represents the descriptive statistics of the sample firms. The average values of LTLR signify that selected companies are low levered firms and they rely more on short-term debt compared to long-term. Further, growth and profitability values are moderately high but lack consistency. Overall, the sample firms can be characterised as growing, moderately levered, and profitable.

Table 2. Descriptive Statistics

\begin{tabular}{|l|c|c|c|c|c|}
\hline \hline \multicolumn{7}{|c|}{ Obs. } & Min & Max & Mean & Std. Dev. \\
\hline \hline \multicolumn{7}{|c|}{ Panel-A: LTLR } \\
\hline Small & 120 & 0.000 & 0.855 & 0.146 & 0.237 \\
\hline Medium & 160 & 0.000 & 0.713 & 0.183 & 0.142 \\
\hline
\end{tabular}


Table 2. Descriptive...

\begin{tabular}{|c|c|c|c|c|c|}
\hline & Obs. & Min & Max & Mean & Std. Dev. \\
\hline Large & 120 & 0.000 & 0.520 & 0.109 & 0.128 \\
\hline \multicolumn{6}{|c|}{ Panel - B: STLR } \\
\hline Small & 120 & 0.003 & 0.922 & 0.220 & 0.211 \\
\hline Medium & 160 & 0.000 & 1.605 & 0.330 & 0.272 \\
\hline Large & 120 & 0.012 & 4.861 & 0.423 & 0.627 \\
\hline \multicolumn{6}{|c|}{ Panel-C: CS Determinants } \\
\hline TAS & 400 & 0.003 & 0.810 & 0.317 & 0.193 \\
\hline LQD & 400 & 0.007 & 6.193 & 1.417 & 0.826 \\
\hline OPGR & 400 & -1.027 & 15.617 & 0.255 & 1.390 \\
\hline PRFT & 400 & -2.666 & 0.517 & 0.081 & 0.230 \\
\hline RTX & 400 & -0.008 & 10.625 & 0.282 & 0.760 \\
\hline NDT & 400 & 0.001 & 0.107 & 0.031 & 0.021 \\
\hline OCFA & 400 & -0.540 & 0.379 & 0.077 & 0.117 \\
\hline
\end{tabular}

S o u r c e : author's calculations, 2020.

\section{Unit root test}

Time series data needs to be checked for stationarity (time invariant mean, variance, and autocovariance) for validating the results of multiple regression analysis (Gujarati, 2003). Augmented Ducky Fuller (ADF) test has been applied for assessing the nature of the series and the results show that all selected variables except DCC are having p-values less than 0.05 (refer table 3) suggesting stationarity of data. DCC has been dropped from further analysis for reliable results.

Table 3. Results of unit toot (ADF) test

\begin{tabular}{|l|c|c|c|}
\hline \hline & ADF Test Statistic & Probability Value & Nature of Series \\
\hline \hline LTLR & -4.447 & 0.000 & Stationary \\
\hline STLR & -10.209 & 0.000 & Stationary \\
\hline
\end{tabular}


Table 3. Results...

\begin{tabular}{|l|c|c|c|}
\hline \hline & ADF Test Statistic & Probability Value & Nature of Series \\
\hline \hline TAS & -5.463 & 0.000 & Stationary \\
\hline LQD & -6.516 & 0.000 & Stationary \\
\hline OPGR & -14.688 & 0.000 & Stationary \\
\hline PRFT & -11.294 & 0.000 & Stationary \\
\hline RTX & -13.314 & 0.000 & Stationary \\
\hline NDT & -6.208 & 0.000 & Stationary \\
\hline OCFA & -12.547 & 0.000 & Stationary \\
\hline DCC & -5.981 & 0.194 & Non - Stationary \\
\hline
\end{tabular}

S o u r c e : author's calculations, 2020.

\section{Correlation analysis}

Table 4 shows the pair-wise correlation among the selected variables. LTLR is positively and significantly related with TAS and NDT and inversely related with LQD, PRFT, RTX and OCFA. The relation of said determinants with STLR is quite different from that of LTLR. Only NDT and RTX is directly associated with STLR whereas PRFT, LQD, TAS, and OCFA are negatively related with the same. Overall, it shows that profitable firms prefer more of equity funds instead of borrowings confirming the findings of POT.

Table 4. Correlation analysis

\begin{tabular}{|l|l|l|l|l|l|l|l|l|l|}
\hline \hline & LTLR & STLR & TAS & LQD & OPGR & PRFT & RTX & NDT & OCFA \\
\hline \hline LTLR & 1 & & & & & & & & \\
\hline STLR & -0.002 & 1 & & & & & & & \\
\hline TAS & $0.350^{* *}$ & $-0.401^{* *}$ & 1 & & & & & & \\
\hline LQD & $-0.192^{*}$ & $-0.377^{* *}$ & $-0.371^{* *}$ & 1 & & & & & \\
\hline OPGR & 0.011 & -0.081 & -0.061 & 0.012 & 1 & & & & \\
\hline PRFT & $-0.157^{*}$ & $-0.789 * *$ & $-0.189 * *$ & $0.229 * *$ & 0.084 & 1 & & & \\
\hline RTX & $-0.142^{*}$ & 0.004 & -0.012 & -0.063 & -0.013 & 0.033 & 1 & & \\
\hline
\end{tabular}


Table 4. Correlation...

\begin{tabular}{|l|c|c|c|c|c|c|c|c|c|}
\hline \hline & LTLR & STLR & TAS & LQD & OPGR & PRFT & RTX & NDT & OCFA \\
\hline \hline NDT & $0.220^{*}$ & $0.162^{*}$ & $0.724^{* *}$ & $-0.232^{* *}$ & -0.058 & $-0.206^{* *}$ & 0.104 & 1 & \\
\hline OCFA & $-0.154^{* *}$ & $-0.349^{*}$ & $0.173^{*}$ & -0.080 & -0.087 & $0.446^{* *}$ & 0.051 & 0.094 & 1 \\
\hline
\end{tabular}

S o u r c e : author's calculations, 2020.

\section{Robustness and diagnostics}

To examine the robustness of results, several diagnostic tests have been performed. First, to check multicollinearity, variance inflation factor (VIF) has been calculated and its highest value among all models is 7.336 and is below the threshold limit of 10 (Gujarati \& Sangeetha, 2007). Secondly, to control autocorrelation, Durbin-Watson (D-W) statistic has been calculated and the computed values (refer table $5 \& 7$ ) are within the allowable limits of 0 to 2 (Gujarati, 2003; Gujarati \& Sangeetha, 2007). Third, to obtain reliable results from t-test (significance of regressors) and F-test (model fit) of regression, Breusch-PaganGodfrey (BPG) test of homoscedasticity (Sathyanarayana et al., 2017) has been applied. Result of BPG test (refer table $5 \& 7$ ) show that p-value is more than 0.05 showing absence of heteroskedasticity.

\section{Econometric results and hypothesis testing}

Table 5 represents the regression output of both models for overall sample firms. The results indicate that TAS, RTX, and OCFA are major determinants of long-term debt ratio. On the other hand, TAS, LQD, and PRFT are significant determinants of short-term borrowings. Both regression models are significant at $1 \%$ level of significance. Further, selected variables can explain higher variation in STLR (67.15\%) compared to LTLR (16.50\%). Table 6 presents the output of hypothesis testing for the whole sample data. 
Table 5. Regression Output (Overall Sample)

\begin{tabular}{|l|l|l|}
\hline \multicolumn{1}{|c|}{ Parameters } & Model - 1 (LTLR) & Model - 2 (STLR) \\
\hline \hline Constant & $0.109(0.004)^{* *}$ & $0.695(0.000)^{* *}$ \\
\hline TAS & $0.355(0.000)^{* *}$ & $-0.426(0.002)^{* *}$ \\
\hline LQD & $-0.019(0.205)$ & $-0.129(0.000)^{* *}$ \\
\hline OPGR & $0.001(0.907)$ & $-0.007(0.560)$ \\
\hline PRFT & $-0.029(0.634)$ & $-1.305(0.000)^{* *}$ \\
\hline RTX & $-0.029(0.055)^{* * *}$ & $0.000(0.989)$ \\
\hline NDT & $0.360(0.659)$ & $1.897(0.113)$ \\
\hline OCFA & $-0.350(0.003)^{* *}$ & $-0.060(0.723)$ \\
\hline$R^{2} /$ Adj. R & $0.194 / 0.165$ & $0.683 / 0.672$ \\
\hline F - Value (sign. value) & $6.610(0.000)$ & $59.111(0.000)$ \\
\hline D-W Stat / VIF & $1.933 / 2.430$ & $1.176 / 2.430$ \\
\hline Heteroskedasticity Test (p-value) & $1.124(0.256)$ & $1.224(0.216)$ \\
\hline $\begin{array}{l}\text { Notes: Values in parenthesis indicates significant value. } \\
\text { * - Sign. at 1\% level *** - Sign. at 10\% level }\end{array}$ & & \\
\hline \hline
\end{tabular}

S o u r c e : author's calculations, 2020.

Table 6. Hypothesis Testing

\begin{tabular}{|l|l|l|}
\hline \hline \multicolumn{1}{|c|}{ Hypothesis } & \multicolumn{1}{c|}{ LTLR } & \multicolumn{1}{c|}{ STLR } \\
\hline \hline $\mathrm{H}_{1}:$ TAS and CS & Accepted & Rejected (significant negative) \\
\hline $\mathrm{H}_{2}:$ LQD and CS & Rejected & Accepted \\
\hline $\mathrm{H}_{3}:$ OPGR and CS & Rejected & Rejected \\
\hline $\mathrm{H}_{4}:$ PRFT and CS & Rejected & Accepted \\
\hline $\mathrm{H}_{5}:$ RTX and CS & Rejected (significant negative) & Rejected \\
\hline $\mathrm{H}_{6}:$ NDT and CS & Rejected & Rejected \\
\hline $\mathrm{H}_{7}:$ OCFA and CS & Accepted & Rejected \\
\hline \hline
\end{tabular}

S o u r c e : author's computation, 2020. 
To analyze the moderation effect, regression analysis has been performed separately for small, medium and large size firms and the results are indicated in table 7. F-test for robustness of model implies that all models are statistically significant ( $p$-values $<0.05$ ). As shown in table 7 , the selected determinants can explain the changes in debt ratios of medium and large firms more effectively than that of small firms. Hence, the study confirms the moderating effect of size on the relationship between CS and its determinants. Table 8 summarizes the critical determinants of CS decision of firms according to their size.

Table 7. Regression Output (Size-wise Analysis)

\begin{tabular}{|c|c|c|c|c|c|c|}
\hline \multirow{2}{*}{ Parameters } & \multicolumn{3}{|c|}{ Model - 1 (LTLR) } & \multicolumn{3}{|c|}{ Model - 2 (STLR) } \\
\hline & Small & Medium & Large & Small & Medium & Large \\
\hline Constant & 0.127 & 0.134 & 0.130 & 0.655 & 0.875 & 0.671 \\
\hline TAS & 0.140 & $0.375^{* *}$ & $0.473 * *$ & $-0.347 * * *$ & $-0.616 * *$ & $-0.536^{*}$ \\
\hline LQD & 0.054 & -0.017 & $-0.043 * *$ & $-0.270 * *$ & $-0.162^{* *}$ & $-0.087 * *$ \\
\hline OPGR & 0.008 & -0.003 & $0.087^{*}$ & -0.017 & 0.003 & $-0.173 * *$ \\
\hline PRFT & -0.346 & 0.022 & 0.091 & $0.884 * *$ & $-0.908^{* *}$ & $-1.633^{* *}$ \\
\hline RTX & $-0.318^{*}$ & -0.015 & -0.154 & -0.068 & -0.005 & $0.584 * *$ \\
\hline NDT & 1.296 & -1.401 & -0.683 & 1.216 & -0.509 & 1.229 \\
\hline OCFA & -0.373 & $-0.305^{* * *}$ & $-0.394 *$ & $-0.532 * *$ & 0.163 & 0.154 \\
\hline $\mathrm{R}^{2}$ & 0.254 & 0.221 & 0.628 & 0.523 & 0.585 & 0.945 \\
\hline Adj. $R^{2}$ & 0.137 & 0.133 & 0.570 & 0.448 & 0.539 & 0.936 \\
\hline F-Value & 2.166 & 2.517 & 10.775 & 6.976 & 12.536 & 109.073 \\
\hline Sign. Value & 0.026 & 0.018 & 0.000 & 0.000 & 0.000 & 0.000 \\
\hline D-W Stat & 1.111 & 0.991 & 1.791 & 1.038 & 1.784 & 1.288 \\
\hline VIF & 3.335 & 1.902 & 7.336 & 3.335 & 1.902 & 7.336 \\
\hline $\begin{array}{l}\text { Heteroske- } \\
\text { dasticity Test } \\
\text { (p-value) }\end{array}$ & $\begin{array}{c}1.516 \\
(0.183)\end{array}$ & $\begin{array}{c}0.732 \\
(0.646)\end{array}$ & $\begin{array}{c}1.573 \\
(0.165)\end{array}$ & $\begin{array}{c}1.530 \\
(0.178)\end{array}$ & $\begin{array}{c}1.340 \\
(0.243)\end{array}$ & $\begin{array}{c}3.132 \\
(0.106)\end{array}$ \\
\hline
\end{tabular}

S o u r c e : author's calculations, 2020. 
Table 8. Determinants of Capital Structure (Size-wise Analysis)

\begin{tabular}{|c|c|c|c|c|c|c|}
\hline \multirow[b]{2}{*}{ Determinants } & \multicolumn{3}{|c|}{ LTLR } & \multicolumn{3}{|c|}{ STLR } \\
\hline & Small & Medium & Large & Small & Medium & Large \\
\hline TAS & & $v$ & $v$ & $\checkmark$ & $v$ & $v$ \\
\hline LQD & & & $v$ & $v$ & v & $v$ \\
\hline OPGR & & & $v$ & & & $v$ \\
\hline PRFT & & & & V & v & $v$ \\
\hline RTX & $v$ & & & & & $v$ \\
\hline \multicolumn{7}{|l|}{ NDT } \\
\hline OCFA & & V & $\checkmark$ & V & & \\
\hline
\end{tabular}

$\sqrt{ }$ : indicates significant factor

S o u r c e : author's computations, 2020.

\section{DISCUSSION OF RESULTS}

Tangibility

TAS is positively related with LTLR indicating that asset tangibility increases long term borrowings. The findings are consistent with past results from Rani et al. (2016), M'ng et al. (2017), and Yousef (2019). On the contrary, STLR is negatively affected by TAS showing that firms that have less fixed assets borrow from short term sources. Tangible assets are pledged against the longterm borrowings hence higher proportion of fixed assets improves the ability to raise long-term loans. Further, tangibility does not affect the borrowing decision of small size as large firms can have better accumulation of tangible assets compared to smaller ones.

\section{Liquidity}

LQD is found to be insignificant factor affecting long term loans as it represents ability of the company to meet it short-term obligations and hence becomes less relevant for long-term loan. Whereas, it has significant negative impact on STLR for overall sample data. It supports the conclusion of POT (Myers \& Majluf, 1984) and TOT (Myers, 1984) as well as Berkman et al. (2016), and Vintila 
et al. (2019). It signifies that firms with higher LQD manage their short-term funds requirement internally and do not rely on external financing. Further, LQD has significant negative impact on LTLR of large firms and STLR of all categories of firms.

\section{Profitability}

PRFT is found to be a weak predictor of long-term borrowings but it has significant negative impact on short term debt for the whole sample data. The findings confirm the conclusion of Bauer (2004), Iqbal et al. (2019) whereas contradicts the results of Dakua (2018) and Rao et al. (2019). The results can be justified as firms with higher profits can have accumulated reserves which can be plough back into the business for financing activities. Further, profitable firms discharge their liabilities to reduce cost of financial distress. Analyzing the size-wise results, it is found that small size firms raise short-term debt with increasing profitability whereas medium and large size firms redeem shortterm debt as their profitability increases. Hence, growing size reduces the level of debt showing negative relation between profits and STLR.

\section{Cash flows}

Consistent with findings of POT and TOT, OCFA has significant negative impact on LTLR confirming the empirical results from Vijayalakshami (2016) and Hossain and Hossain (2015). Similar to profitability, surplus cash flows are utilised to pay outstanding debt and firms become self-sufficient as far as financing burden is concern. Further, increasing cash flows are reinvsted in the business to fund new and/or existing operations. Cash flows do not have significant effect on short term borrowings other than for small size firms.

\section{Implications and future scope of research}

The findings of the study have several implications and are valuable for academicians, scholars and practitioners. The study contributes to existing body of knowledge by examining the determinants of debt financing moderated by firm size in emerging market like India. The study has several practical implications for corporate managers as the findings will be help them in forming 
their borrowing strategies based on the relative size. The managers can identify necessary factors to be considered while choosing debt or equity as well as in case of debt either short term or long term.

Present research work can be extended by taking multiple industries and findings can be compared as against single industry. Based on the relation between profit and short-term debt stated above, researchers can study changes in CS during the life cycle of the firm. Besides, factors like government regulation, management policies, and capital market norms can be included for analyzing borrowing decisions.

\section{ConCLUSION}

In countries like India where financial markets are under developing stage, financing decision becomes very critical and it plays an important role in determining firms' profitability. This research paper mainly focuses on determinants of CS choice of Indian food processing companies and examines the moderating effect of firm size. The study concludes tangibility, tax rate, and cash flow as significant determinants of long-term debt whereas tangibility, liquidity and profitability are significant causes of short-term debt for overall sample firms. Further, the study confirms the moderating role of firm size as strength of various factors varies according to firm size. The results indicate positive relation between profitability and short-term debt ratio for small size companies whereas negative relation for medium and large size companies. It advocates that increasing profits induce small firms to borrow more but as firms grow up in size, they replace debt with own funds showing inverse relationship. Hence, the relation between same variables is moderated significantly by size of the firm.

\section{REFERENCES}

Abor, J. (2005). The Effect of Capital Structure on Profitability: An Empirical Analysis of Listed Firms in Ghana. The Journal of Risk Finance, 6(5), 438-445. http://dx.doi. org/10.1108/15265940510633505.

Abor, J. (2007). Debt policy and performance of SMEs Evidence from Ghanaian and South African firms. The Journal of Risk Finance, 8(4), 364-379. http://dx.doi.org/ $10.1108 / 15265940710777315$. 
ACARAVCI, S. (2015). The Determinants of Capital Structure: Evidence from the Turkish Manufacturing Sector. International Journal of Economics and Financial Issues, 5(1), 158-171.

Aggarwal, A., \& Acharya, S. (2019). Impact on capital structure decision making: Indian medium-sized food industry analysis. Copernican Journal of Finance \& Accounting, 8(4), 47-60. http://dx.doi.org/10.12775/CJFA.2019.017.

Banerjee, A., \& De, A. (2014). Determinants of Corporate Financial Performance Relating to Capital Structure Decision in Indian Iron and Steel Industry: An Empirical Study. Paradigm, 18(1), 35-50. http://dx.doi.org/10.1177/0971890714540365.

Bauer, P. (2004). Determinants of Capital Structure Empirical Evidence from the Czech Republic. Finance a úvûr - Czech Journal of Economics and Finance, 54(1-2), 2-21.

Berkman, N., İskenderoğlu, Ö., Karadeniz, E., \& Ayyildiz, N. (2016). Determinants of Capital Structure: The Evidence from European Energy Companies. International Journal of Business Administration, 7(6), 96-106. http://dx.doi.org/10.5430/ijba. v7n6p96.

Bhaduri, S. (2002). Determinants of Corporate Borrowing: Some Evidence from the Indian Corporate Structure. Journal of Economics and Finance, 26(2), 200-215. http:// dx.doi.org/10.1007/BF02755986.

Brand India (2017). Indian Food Industry, http://www.ibef.org/archives/detail/b3ZlcnZpZXcmMzcxNTImNDk0 (accessed: 15.01.2020).

Dakua, S. (2018). Effect of determinants on financial leverage in Indian steel industry: A study on capital structure. International Journal of Financial Economics, 24(1), 427-436. http://dx.doi.org/10.1002/ijfe.1671.

DeAngelo, H., \& Masulis, R. (1980). Optimal Capital Structure under Corporate and Personal Taxation. Journal of Financial Economics, 8(1), 3-29. http://dx.doi. org/10.1016/0304-405X(80)90019-7.

Donaldson, G. (1961). Corporate debt capacity: A study of corporate debt policy and the determination of corporate debt capacity. Division of Research, Graduate School of Business Administration, Harvard University.

Durand, D. (1952). Cost of Debt and Equity Funds for Business: Trends and Problems of Measurement. Conference on Research in Business Finance. New York: National Bureau for Economic Research.

Fama, F., \& French, R. (1998). Taxes, Financing Decisions, and Firm Value. The Journal of Finance, 53(3), 819-843. http://dx.doi.org/10.1111/0022-1082.00036.

Gujarati, D. (2003). Basic Econometrics (4th ed.). New York: McGraw Hill.

Gujarati, D., \& Sangeetha, N. (2007). Basic Econometrics. New Delhi: McGraw Hill.

Gupta, P. (2015). An empirical study of relationship between capital structure and profitability of foreign promoters holding companies in India. BVIMR Management Edge, 8(1), 80-91.

Hossain, M., \& Hossain, M. (2015). Determinants of Capital Structure and Testing of Theories: A Study on the Listed Manufacturing Companies in Bangladesh. International Journal of Economics and Finance, 7(4), 176-190. http://dx.doi.org/10.5539/ ijef.v7n4p176. 
Iqbal, F., Ahmad, B., \& Ali, F. (2019). Determinants of Capital Structure: An Empirical Study of KSE Listed MNCs in Pakistan. Journal of Accounting, Finance and Auditing Studies, 5(1), 173-195. http://dx.doi.org/10.32602/jafas.2019.8.

Jensen, M., \& Meckling, W. (1976). Theory of the firm: Managerial behavior, agency costs and ownership structure. Journal of financial economics, 3(4), 305-360. http:// dx.doi.org/10.1016/0304-405X(76)90026-X.

Karadeniz, E., Kandir, Y., Balcilar, M., \& Onal, B. (2009). Determinants of capital structure: evidence from Turkish lodging companies. International Journal of Contemporary Hospitality Management, 21(5), 594-609. http://dx.doi.org/10.1108/09596110910967827.

Kazmierska-Jozwiak, B., Marszalek, J., \& Sekula, P. (2015). Determinants of Debt-Equity Choice - Evidence From Poland. Emerging Markets Journal, 5(2), 1-8. http://dx.doi. org/10.5195/emaj.2015.76.

Mallikarjunappa, T., \& Goveas, C. (2007). Factors Determining the Capital Structure of Pharmaceutical Companies in India. The ICFAI Journal of Applied Finance, 13(11), 56-72.

Mayuri, T., \& Kengatharan, L. (2019). Determinants of Capital Structure: Evidence from Listed Manufacturing Companies in Sri Lanka. SCMS Journal of Indian Management, 43-56.

Ministry of Food Processing Industries (2019). Ministry of Food Processing Industries, Mega Food Parks, National Mission on Food Processing, http://www.mofpi.nic.in (accessed: 12.01.2020).

Mittal, K., \& Singla, K. (1992). Determinants of Debt-Equity Mix. Finance India, 6, 299-306.

M’ng, C., Rahman, M., \& Sannacy, S. (2017). The determinants of capital structure: Evidence from public listed companies in Malaysia, Singapore and Thailand. Cogent Economics \& Finance, 5, 1-34. http://dx.doi.org/10.1080/23322039.2017.1418609.

Modigliani, F., \& Miller, M. (1963). Corporate income taxes and cost of capital: A correction. American Economic Review, 53(3), 433-443.

Modigliani, F., \& Miller, M. (1958). The Cost of Capital, Corporate Finance and the Theory of Investment. American Economic Review, 48, 261-297.

Myers, S. (2003). Still searching for optimal capital structure. In S. Myers (Ed.). The Revolution in Corporate Finance (4th ed.). Hoboken: Blackwell Publishers.

Myers, S. (1984). The capital structure puzzle. Journal of Finance, 39(3), 575-592. http:// dx.doi.org/10.1111/j.1540-6261.1984.tb03646.x.

Myers, S., \& Majluf, S. (1984). Corporate financing and investment decisions when firms have information that investors do not have. Journal of Financial Economics, 13(2), 187-222. http://dx.doi.org/10.1016/0304-405X(84)90023-0.

Ramaratnam, M., \& Jayaraman, R. (2013). Determinants of Capital Structure with special reference to Indian Pharmaceutical Sector: Panel Data Analysis. Journal of Commerce and Accounting Research, 2(4), 45-50.

Ramli, A., Latan, H., \& Solovida, G.T. (2019). Determinants of capital structure and firm financial performance - A PLS-SEM approach: Evidence from Malasiya and Indo- 
nesia. The Quarterly Review of Economics and Finance, 71, 148-160. http://dx.doi. org/10.1016/j.qref.2018.07.001.

Rani, A., Narain, \& Dhawan, S. (2016). Determinants of Leverage Decision of Indian Firms: An Empirical Stuy. Business Analyst, 37(1), 19-30.

Rao, P., Kumar, S., \& Madhvan, V. (2019). A study on factors driving the capital structure decisions of small and medium enterprises (SMEs) in India. IIMB Management Review, 31(1), 37-50. http://dx.doi.org/10.1016/j.iimb.2018.08.010.

Ross, S. A. (1977). The determination of financial structure: The incentive signalling approach. The Bell Journal of Economics, 8(1), 23-40.

Sathyanarayana, S., Harish, S., \& Kumar, H. (2017). Determinants of Capital Structure: Evidence from Indian Stock Market with Special Reference to Capital Goods, FMCG, Infrastructure and IT sector. SDMIMD Journal of Management, 8(1), 55-73.

Vijayalakshami, D. (2016). Determinants of Leverage: Indian Transport Equipment Sector. SCMS Journal of Indian Management, 13(1), 81-90.

Vintila, G., Gherghina, S., \& Toader, D. (2019). Exploring the Determinants of Financial Structure in the Technology Industry: Panel Data Evidence from the New York Stock Exchange Listed Companies. Journal of Risk and Financial Management, 12(163), 1-16. http://dx.doi.org/10.3390/jrfm12040163.

Yousef, Y. (2019). The Determinants of Capital Structure: Evidence From GCC and UK Real Estate Sectors. Real Estate Management and Valuation, 27(2), 108-125. http:// dx.doi.org/10.2478/remav-2019-0019. 